Универзитет у Београду Филолошки факултет, Београд

DOI 10.5937/kultura1338179J

УДК 821.163.41.09-1 Црњански М. 821.521.09-1

$821.581 .09-1$

прегледни рад

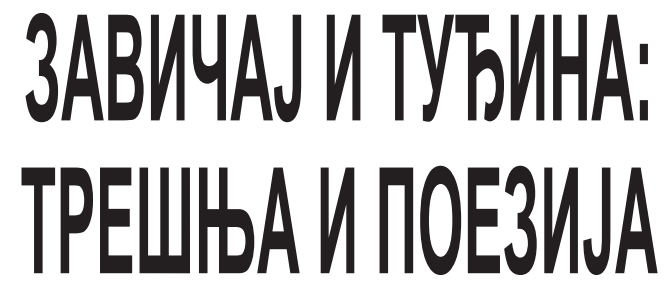
МИМOША LPHAHCCКГГ

Сажетак: Милош Црњански је упознао поезију Истока у Паризу крајем 1920. године, где је сакупьао грађу за кинеску и јапанску антологију песама. То је тренутак када се и у његовом стваралаштву појављује ивет трешања, а не плод. Током сакупљања и обликовања двеју преведених збирки поезије “Антологија кинеске лирике" (1923) и "Песме старог Јапана" (1928), настале су песме Милоша Црњанског у којима се слика расиветане трешъе појављује као важан симболичан топос.

Кључне речи: Милош Црњански, поема Стражилово, авангардна поезија, интертекстуалност

По једна љубав, јутро, у туђини,

душу нам увија, све тешње,

бескрајним миром плавих мора,

из којих црвене зрна корала,

као, из завичаја, трешње. ${ }^{1}$

Трешња у песми „Суматра“ (1920), уз слику завичаја, руменом бојом повезана је са бесконачним воденим и са небеским простором. Она је важан елемент суматраизма. ${ }^{2}$ Као

1 Црњански М., Лирика, у: Дела Милоша Црњанског, Том 1, Задужбина Милоша Црњанског, Београд 1993.

2 Текст је настао у оквиру пројекта Књижевности и визуелнне уметности: руско-српски дијалог Министарства науке Репблике Србије бр. 178003. То је прерађена и допуњена верзија научног рада Трешњев иявет и поезија Милоша Црњанског, објављеног у зборнику радова Језик, књи- 


\section{КАЈОКО ЈАМАСАКИ}

плодови црвене боје, у поређењу са коралом, чине контраст са плавом бојом морске површине. Овде, трешња нас упућује на завичај, доживљен издалека.

Трешња, у виду румених плодова, појављује се и у његовом програмском тексту, „Објашњење 'Суматре”“ (1920), уз следећу завичајну слику:

„Помислих: како ли ће ме дочекати мој завичај. Трешње су сада свакако румене, а села су сад весела. Гле, како су и боје, чак тамо до звезда, исте, и у трешања, и у корала! Како је све у вези, на свету““3.

Откако се Црњански упознао са поезијом Истока у Паризу крајем 1920. године, где је сакупио грађу за кинеску и јапанску антологију песама, у његовом стваралаштву се више пута јавља цвет трешања, а не плод. Током настајања две збирке преводне поезије Антологија кинеске лирике (1923) и Песме старог Јапана (1928), настале су и његове песме у којима се налази слика расцветане трешње. Међу тим песмама је и поема „Стражилово“. Као што запажа А. Петров, учесталост мотива цветова, нарочито трешње, представља траг „источног“ утицаја, у Паризу и после Париза. ${ }^{4}$

Трешњев цвет појављује се у следећим његовим песмама: „Посланица из Париза“ (1920); „Поворка“ (1921); „Сербиа“ (1925); „Стражилово“ (1921-1929).

У „Посланици из Париза“ (1920) постоји слика, која приказује бестелесну љубав. Активирањем чула додира, трешњев цвет ствара суптилну, али сензуалну слику:

Тела ће вам се изгубити

и крв бити све тања и тања;

занемели ћете љубити

врхове цветних трешања. ${ }^{5}$

У песми „Поворка“ (1921) помиње се трешња у четвртој строфи, у облику дрвета у покрету:

жевност, култура: Новици Петковићу у част (2011). Рад је прочитан на научном скупу Сусретања култура: Јапан и Србија - 130. годищњица српско-јапанске сарадње, одржаном 17. и 18. децембра 2012. године у Народној библиотеци Србије у Београду.

3 Црњански М., Есеји и чланци I, у: Дела Милоша Црњанског, Том 10, Задужбина Милоша Црњанског, Београд 1999.

4 Петров А., Црњански и поезија Истока, у: М. Црњански. Антологија кинеске лирике и Песме старог Јапана, Народна библиотека Србије, Београд 1990, стр. 1-21.

5 Црњански М., Лирика, у: Дела Милоша Црғанског, Том 1, Задужбина Милоша Црњанског, Београд 1993. 
Мисли ми јасне ишчезнуше, у непрекидном смешењу тамном.

А полако се скупише, са свих страна, поворке процвалих трешања, да пођу, пођу, са мном. ${ }^{6}$

Расцветана трешња постаје основни мотив у његовој поеми „Стражилово“ (1921-1929), која је настајала за време превођења и објављивања поезије са Истока. Песма почиње следећом строфом, која се понавља као и седма. У поеми трешњев цвет (расцветане трешње) има више значења. С једне стране он се односи на сенку, болест и страх, а са друге, на живот, стишавање и смиреност. Трешња се прво јавља уз слику завичаја, који се слути. Завичај се помиње уз слику сахрањивања смеха, под јаблановима:

Лутам, још, витак, са сребрним луком, расцветане трешње, из заседа, мамим, али, иза гора, завичај већ слутим,

где ћу смех, под јаблановима самим, да сахраним. ${ }^{7}$

У тридесет осмој строфи трешња, као дрво, заједно са вишњом, обавијено маглом, нуди нам слику живота, који се полако стишава, у умирању. То нас подсећа на будистички идеал човековог живота, тј. нирвану:

А, над трешњама и младим вишњама, тамну и дугу маглу, што се, свуда, шири, у живот пред нама, где се страст, полако, у умирању смири, и чула упокоје. ${ }^{8}$

У поеми „Сербиа“ (1925) трешња се појављује једанпут, у трећој строфи:

Нисам знао да ми, трешњом, и бистрим потоком, и страсном виткошћу девојке, њином притоком, Она то већ, из далека, колена пребија!'

У песми налазимо изразе расцветан и цветан као што су „Расцветане падине“, „Расцветани Срем“. Као приређивач збирке Песме старог Јапана, Црњански је знао да трешњев цвет симболизује пролазности у јапанској култури. Онда, по

\footnotetext{
6 Исто.

7 Исто.

8 Исто.

9 Исто.
} 
свој прилици, није случајно што се реч пролазност у песми „Сербиа“ јавља овако:

Кад, у сутон, преливају облаци, као слап, пролазност, у којој смо сви, у провидној сузи. ${ }^{10}$

У песмама М. Црњанског, које смо помињали, трешња, а нарочито трешњев цвет, има посебну симболику. Она гради ваздушасту, прозрачну, етеричну, али често покретну песничку слику. У тој слици се претапају светлост и тама, радост и туга, телесно и бестелесно, живот и смрт. Трешњево дрво, обавијено маглом, ствара необичну слику у којој се све стишава, у наручју природе. Она је, можда, срж метафизичког, трансцендентног света М. Црњанског.

Пре него што отворимо Песме старог Јапана да бисмо расветлили како је Црњански схватио трешњев цвет у јапанском песништву, било би потребно да говоримо о значају овога цвета у јапанској традицији.

Трешњев цвет (сакура) има посебан значај у јапанској култури. За разлику од кинеске или европске трешње која рађа плодове, аутохтона јапанска трешња само цвета, без јестивих плодова. У хаику поезији мотив трешњевог цвета, као киго, реч која одређује годишње доба стиха, означитељ је пролећа. Понеки израз гради необичну, префињену песничку слику: цветни облак значи „шума или брег расцветаних трешања“: када се гледа издалека, трешњево цвеће у шуми или на брегу изгледа као ружичасти облак. Свакако, ова песничка слика подсећа нас на већ поменуто „Стражилово“. Разноврсност мотива трешњевог цвета потврђује не само танани осећај за природу, већ је доказ да је мотив трешњевог цвета или цвета дубоко урезан у живот, мисао, колективно памћење Јапанаца.

Кроз историју, реч цвет или трешњев цвет упућивала је Јапанце на нешто што се односи на смисао живота или суштину лепог, које брзо пролази. У древној књижевности, налазимо мотив цвета (трешњевог цвета) у најстаријој збирци песама Ман'јошу (VIII). У њој једна елегија пева о смрти прелепе девојке Сакурако (девојка цвећа трешње), за којом тугују двојица момака.

Касније, у Хеиан периоду (VIII-XII), за време дворске књижевности, и племенити људи су видели у цветовима трешње симбол живота, а видели су и лепоту у раскошном цветању. Благо ружичаста боја постала је омиљена међу дворским дамама. Младе даме су носиле плашт тзв. сакура гасане

10 Исто. 
(трешњеви слојеви, или плашт трешања): лице је било бело, а наличје румено, као латице трешања. У то доба трешњев цвет се односио на префињено, благо, светло као лепо, а песничка слика била је везана за стварну појавност.

У средњовековној књижевности (XII-XVI), за време непрекидних ратова међу клановима војсковођа, за време немира и несталности, песници су певали више о опадању трешњиних цветова. Значење трешњевог цвета померено је од појавности ка непојавности, од живота ка смрти, од радости ка тузи. Монах Јошида Кенко (1283?-1352?) у своме делу Цурезурегуса (1331) каже овако: „Зар да уживамо цвеће само када је у цвату, а месец само када је пун? Чак је и лепше и боље када чезнеш за месецом по киши, и да не знаш куда иде пролеће, док се затвараш у соби“"11. Његов став означава суштинску промену у поимању лепог. Уместо видљиво лепог, уводи се невидљиво или непостојеће као лепо. То је блиско поимању лепог код Црњанског, који често гради паралелни свет, свет сновиђења. Мотив цвета почео је да наговештава сету, тугу, непостојање, нестајање или ишчезавање свега постојећег. У то доба настаје и изрека „Цвеће је трешња, а човек ратник“. Обилно цветање трешње, које изузетно кратко траје, често се поредило са животом самураја, спремног на свој достојанствени крај: самовољну смрт. Опадање латица постаје идеал завршетка живота ратника.

Трешњев цвет кроз историју био је везан за крхкост, пролазност, или несталност. Посебно у средњовековној књижевности, представљао је невидљиво, нестално као лепо, што нас асоцира на поетику Милоша Црњанског.

У збирци Песме старог Јапана, коју је Црњански приредио, налазимо доста песама са мотивом трешњевог цвета. Књига садржи укупно 98 песама, а од тога, 24 песме су са мотивом цвећа, и везане су за пролеће. Међу тим песмама налазе се: 16 песама са мотивом трешњевог цвета; 5 песама са мотивом шљивиног цвета; по једна песма са камелијом/анемоном/дивљом ружом.

Број песама са мотивом трешњевог цвета, може се рећи, доиста је велики у овој збирци. Преводи јапанских песама са европских језика, којима се служио српски песник, свакако су му пружили и друге песме са другим мотивима. Ова чињеница наговештава да је трешњев цвет посебно занимао српског песника. Његове Песме старог Јапана садрже стихове не само са сликом цветања трешања, већ и са сликом опадања цветова. Тиме српским читаоцима нуди нову

11 Yoshida K., Tsureyuregusa, Kodansha, Tokyo 1972. 
песничку слику света, који је у сталном настајању, али и у нестајању. Црњански је као мото свом предговору Песме старог Јапана написао ове стихове: „О трешњев цвете, како си сличан животу“12. Када пажљиво читамо његове препеве песама са мотивом цвета и коментаре, биће нам јасно да је Црњански веома свесно укључивао трешњев цвет, као симболику пролазног света.

Из Збирке Ман 'јошу (VIII), налази се вака песма (5/7/5/7/7) о цвету шљиве, коју је написао Окура (Јаманоуено Окура). Цветови шљиве, који су се у то време посебно ценили због изванредног мириса, представљали су префињену кинеску културу. Уз ову песму стоји коментар у којем се јавља реч пролазност: „Тако је блага и она снохватица са цветом шљиве, који се бацао у вино, да би мирисало, као што се цвеће трешања, симбол пролазности, метало у чај“. ${ }^{13}$

Из Хеиан периода, из доба дворске књижевности, Црњански је одабрао вака песме са мотивом цвета из збирке Кокиншу (905), једне од најважнијих збирки поезија у јапанској књижевној историји. Следећа је песма веома познате песникиње Ононо Комаћи. Цвеће (трешње, по песничкој конвенцији) јавља се у метафори за женску лепоту, која је пролазна:

Цвеће ми свену

у дугој ноћној киши.

Прошла сам светом,

загледана у себе,

узалуд. ${ }^{14}$

Црњански је уврстио и песму о трешњевом цвећу коју је написао Кино Томонори (?-905?). У њој је слика о немирном опадању цветова трешње, док се у позадини види мирно пролетње небо.

Зар и данас,

кад је пролетње небо

тако мирно,

немирно цвеће трешања

опада ${ }^{15}$

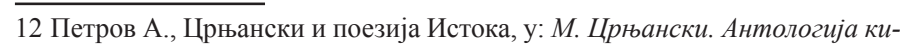
неске лирике и Песме старог Јапана, Народна библиотека Србије, Београд 1990, стр. 1-21; Црњански М., Лирика, у: Дела Милоша Црњанског, Том 1, Задужбина Милоша Црњанског, Београд 1993.

13 Црњански М., Лирика, у: Дела Милоша Црњанског, Том 1, Задужбина Милоша Црњанског, Београд 1993., стр. 442.

14 Црњански М., Лирика, у: Дела Милоша Црњанског, Том 1, Задужбина Милоша Црњанског, Београд 1993.

15 Црњански М., Лирика, у: Дела Милоша Црњанског, Том 1, Задужбина Милоша Црњанског, Београд 1993, стр. 478; Kokinwakashu, Iwanamisho- 
При крају одељка Хеиан периода, налазимо превод следеће песме „Ироха ута“, у коју је уткана будистичка идеја о несталности:

Мада красно шарени

цвеће свене.

Што би и могло бити

вечно на свету?

Далека брда пролазности, пређем ли данас,

бар нећу гледати празне снове, ни опијати се светом. ${ }^{16}$

Уз ову песму Црњански даје објашњење: „Те песме су сасвим будистичке, песимистичке, са радошћу пролазности“. ${ }^{17}$ Ове речи такође показују да се Црњански занимао за будистичку идеју о пролазном свету.

Збирка укључује и песму М. Башоа, са мотивом облака цвећа. Лака и ваздушаста, ова светлосна слика враћа нас поново у суматраизам. Башо пева о цветању трешања у областима Уено и Асакуса (у препеву погрешно стоји као Јено). У песми се мешају чуло слуха и чуло вида:

Читав облак цвећа,

Звони. Да л’ у Јену,

или Асакуси?

Поред идеје о пролазности, српског песника је привукло јапанско поимање природе, чврста веза између човека и природе. У коментарима Црњански даје објашњење о односу Јапанаца према природи: „Скоро сваки од тих стихова пева, хвали, милује, грли, природу. Дрво, цвет, неки пејсаж, годишње доба, или какву тицу, или какво брдо, пут, воду. Та безгранична, будистичка љубав и мешање свога бића са природом, није ново у јапанској лирици“ ${ }^{18}$

У даљем тексту налазимо и следеће његове речи: „Песник хаикаија воли сваки покрет биља и животиња, и у својој безграничној, будистичкој љубави и самилости, сматра се близак инсекту, дрвећу, свему што цвета и прецвета, свему што бива и прође $\mathrm{e}^{\text {“19. }}$. Могли бисмо рећи да овим редовима

ten, Tokyo 1973.

16 Црњански М., Лирика, у: Дела Милоша Црғанског, Том 1, Задужбина Милоша Црњанског, Београд 1993, стр. 488.

17 Исто, стр. 477.

18 Исто, стр. 482.

19 Исто, стр. 485. 
Црњански представља будистички поглед на свет, схватање о пролазности, синхронизованој са природним бићима:

Као што се види из Песама старог Јапана, Црњански је схватио значење трешњевог цвета у јапанској књижевности, и његову мисаоност. Идеја да трешњево цвеће симболизује пролазност, или променљивост свега постојећег осећа се највише у средњовековној књижевности, која се заснива на зен-будистичкој мисли. Средњи век у Јапану, доба немира и ратова, подсећа нас на време настајања поезије, али и на време живота М. Црњанског. У његовој песми, у „Ламенту над Београдом“, запазили смо француски израз tout passe, или „Прошлост“, „прошло“20. Пролазност јесте једна од битних тема којима се Црњански бавио у својој поезији, али и у животу. Том темом он се бавио и кроз превођење поезије Истока.

У песмама које су настале после песниковог сусретања са јапанском поезијом, приметили смо трешњев цвет у динамизованој слици природе: „поворке процвалих трешања, да пођу, пођу, са мном.“ („Поворка“); , ,јер, са мном, цветно дрво, већ уморно корача“ („Стражилово“). Поступак динамизације природе, у коме се врши инверзија агенса и пацијенса, користили су авангардни песници широм света. Код Црњанског, међутим, видимо иза овог поступка његово схватање о природи, сродно јапанском. Црњански, који је приметио „будистичку љубав и мешање свога бића са природом“", у јапанској култури, створио је необичну слику трешњевог дрвета у покрету: трешња која иде са песничким субјектом, тј. дрво које корача са човеком.

Трешња је стигла у песништво Милоша Црњанског са Истока, из крајева у којима песник никада није боравио. Она је истовремено везана за стварну слику његовог завичајног Срема, али је он одатле одавно отишао. Везана је и за реалну слику туђине, као што је она у Тоскани, где је песник странац. Трешњев цвет, може се рећи, спаја три простора: далеки, недостижни завичај, који је песнички субјекат напустио; туђина у којој је он присутан као странац; далеки предео, у коме песнички субјекат никада није био.

У поезији Милоша Црњанског трешњев цвет, који је стигао са Истока, не нуди само нову суптилну песничку слику, већ нам даје нов поглед на свет, ново схватање пролазног променљивог света у коме се налазимо. Како ћемо схватити и прихватити пролазност, несталност овога света? Какав однос треба да гради човек према природи? Одговор на

20 Исто, стр. 108. 
ова питања Црњански је, између осталог, тражио у поезији Јапана, у слици расцветане трешње.

\section{ЛИТЕРАТУРА:}

Кођики-записи о древним догађајима, превео: Вукелић Х. Ј., Васић Д., Кличковић Д., Глумач, Београд.

Црњански М., Лирика, у: Дела Милоша Црњанског, Том 1, Задужбина Милоша Црњанског, Београд 1993.

Црњански М., Есеји и чланци I, у: Дела Милоша Црњанског, Том 10, Задужбина Милоша Црњанског, Београд 1999.

Петковић Н., Лирске епифаније Милоша Црњанског, Српска књижевна задруга, Београд 1996.

Петров А., Црњански и поезија Истока, у: М. Црғански. Антологија кинеске лирике и Песме старог Јапана, Народна библиотека Србије, Београд 1990, стр. 1-21.

Петров А., Поезија Црњанског и српско песништво, Нолит, Београд 1988.

Поповић Р., Црњански - документарна биографија, Просвета, Дечје новине, Београд 1993.

Раичковић С., Кинеска прича, БИГЗ, Београд 1995.

Haiku saijiki (Речник означитеља годишњих доба у хаику поезији), Kadokawa shoten, Tokyo1979.

Јамасаки К., Милош Црњански и Песме старог Јапана, у: Къижевна историја XXV, Београд 1993, стр. 379-385.

Јамасаки К., Бусон у Песмама старог Јапана-Црњански и појам природе, у: Годишњак Катедре за српску књижевност са јужнословенским књижевностима, Година IV, Београд 2008, стр. 221232.

Karaki J., Nihonjin no kokoro no rekish I (Историја душе Јапанаиа I) Chikuma, Tokyo 1985.

Kokinwakashu, Iwanamishoten, Tokyo 1973.

Manyoshu 1, Iwanamishoten, Tokyo 1972.

Manyoshu 4, Iwanamishoten, Tokyo 1972.

Nihon bungaku jiten (Речник јапанске литературе), Heibonsha, Tokyo 1982.

Nihon meika shusei (Антологија јапанских песама), Gakutosha, Tokyo 1992.

Ooka M., Shi, kotoba, ningen (Поезија, реч и човек), Kodansha, Tokyo 1985.

Ooka M., Shika kotohajime (Увод у песништво), Kodansha, Tokyo 1985. 


\section{КАЈОКО ЈАМАСАКИ}

Sekai dai hyakka jiten, XII (Велика енцииклопедија света), Tokyo 1981, стр. 208-209.

Teruoka Y., Teruoka Yasutaka no Kigo jiten (Речник означитеља годишьих доба у хаику поеизији), Tokyodo shuppan, Tokyo 2002.

Yoshida K., Tsureyuregusa, Kodansha, Tokyo 1972.

Yoshino Y., Nihonjin no seishi kan (Јапански поглед на живот и cмpm), Kodansha, Tokyo 1982.

Ariyoshi T., Waka jiten (Речник вака поезије), Ofusha, Tokyo 1982. Zeami, Fushikaden, Iwanami shoten, Tokyo 1994.

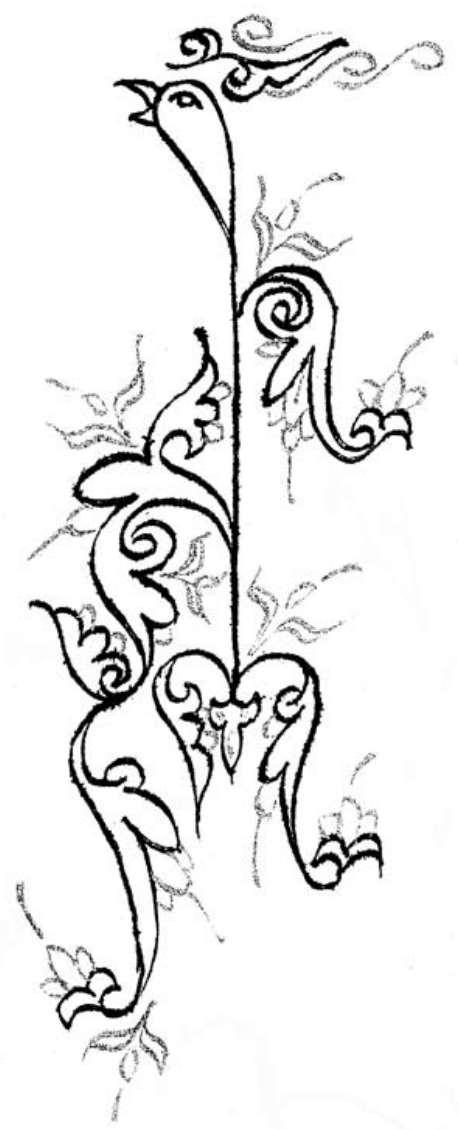


КАЈОКО ЈАМАСАКИ

Kayoko Yamasaki

University of Belgrade, Faculty of Philology, Belgrade

\title{
HOMELAND AND FOREIGN LAND: CHERRY TREE AND POETRY OF MILOŠ CRNJANSKI
}

\begin{abstract}
Miloš Crnjanski became familiar with the poetry of the East in Paris, towards the end of the 1920s, when he gathered material for his anthology of Chinese and Japanese poems. This was the moment when cherry blossom, not cherry fruit, entered his writings. While preparing and editing two collections of translated poetry Antologija kineske lirike (1923) and Pesme starog Japana (1928), he also wrote poems featuring the image of cherry blossom as an important symbolic topos. In his poems Sumatra (1920), Poslanica iz Pariza (1920), Povorka (1921), Serbia (1925) and Stražilovo (1921-1929) cherry trees appear to carry a particular symbolic message, especially the blossom. It creates a light, translucent, ethereal and often even mobile poetic image. This image blends the light and the dark, joy and sorrow, physical and metaphysical, life and death. The cherry tree consumed by fog creates an unusual picture in which everything simmers down in the arms of the nature. It may well be the very heart of the metaphysical, transcendental world of Miloš Crnjanski.The cherry entered his poetics from the East, from the lands he had never visited. At the same time, it created a real bond with his native Srem which he had left years before. It was connected to a real image of a foreign land, like Tuscany, where the poet was but a stranger. We can say that cherry blossom connects three spatial entities: the far-away homeland left behind by the poet; the foreign land where he lives as a stranger; and a distant landscape he had never visited.
\end{abstract}

Key words: Miloš Crnjanski, poem Stražilovo, avant-garde poetry, intertextuality 